\title{
SpringerBriefs in Philosophy
}

For further volumes:

http://www.springer.com/series/10082 
Jennifer Bullington

\section{The Expression of the Psychosomatic Body from a Phenomenological Perspective}

第 Springer 
Jennifer Bullington

Ersta Sköndal University College

Stockholm

Sweden

ISSN 2211-4548

ISBN 978-94-007-6497-2

DOI 10.1007/978-94-007-6498-9

Springer Dordrecht Heidelberg New York London

Library of Congress Control Number: 2013933017

(C) The Author(s) 2013

This work is subject to copyright. All rights are reserved by the Publisher, whether the whole or part of the material is concerned, specifically the rights of translation, reprinting, reuse of illustrations, recitation, broadcasting, reproduction on microfilms or in any other physical way, and transmission or information storage and retrieval, electronic adaptation, computer software, or by similar or dissimilar methodology now known or hereafter developed. Exempted from this legal reservation are brief excerpts in connection with reviews or scholarly analysis or material supplied specifically for the purpose of being entered and executed on a computer system, for exclusive use by the purchaser of the work. Duplication of this publication or parts thereof is permitted only under the provisions of the Copyright Law of the Publisher's location, in its current version, and permission for use must always be obtained from Springer. Permissions for use may be obtained through RightsLink at the Copyright Clearance Center. Violations are liable to prosecution under the respective Copyright Law. The use of general descriptive names, registered names, trademarks, service marks, etc. in this publication does not imply, even in the absence of a specific statement, that such names are exempt from the relevant protective laws and regulations and therefore free for general use.

While the advice and information in this book are believed to be true and accurate at the date of publication, neither the authors nor the editors nor the publisher can accept any legal responsibility for any errors or omissions that may be made. The publisher makes no warranty, express or implied, with respect to the material contained herein.

Printed on acid-free paper

Springer is part of Springer Science+Business Media (www.springer.com) 


\section{Contents}

Introduction $\ldots \ldots \ldots \ldots \ldots \ldots \ldots \ldots \ldots \ldots \ldots \ldots \ldots$ vii

1 The Psychosomatic Problematic . . . . . . . . . . . . . . . . . 1

Summary of Traditional Psychosomatic Theories ............ 3

The Clinical Challenges of Psychosomatic Pathology . . . . . . . . . 13

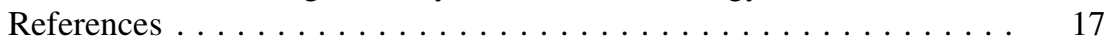

2 The Lived Body . . . . . . . . . . . . . . . . . . . . . . . 19

Phenomenology. . . . . . . . . . . . . . . . . . . . . 19

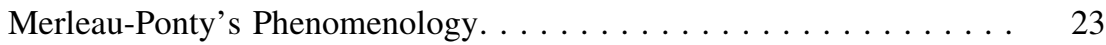

The Body and the World (Lived Body) . . . . . . . . . . . . 25

Structure and Structure Transformation ............... 33

References ........................... 37

3 The Meaning of Meaning . . . . . . . . . . . . . . . . . 39

Merleau-Ponty on Meaning and Expression . . . . . . . . . . . . . . . . . 42

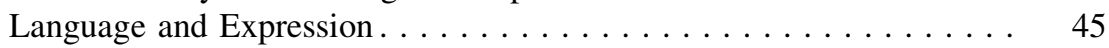

References .............................. 47

4 The Lived Body (Phenomenology of Perception)

and the Flesh (The Visible and the Invisible) . . . . . . . . . . . . . . . . . . . . . . . . . . . . . . .

From Lived Body to Flesh . . . . . . . . . . . . . . . . . . 51

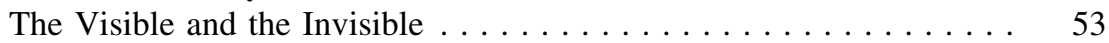

References .......................... 57

5 The Phenomenological Psychosomatic Theory . . . . . . . . . . . . . . 59

The Collapse in Meaning-Constitution and the Failure

of Structure Transformation $\ldots \ldots \ldots \ldots \ldots \ldots \ldots \ldots \ldots \ldots \ldots \ldots \ldots \ldots \ldots \ldots \ldots \ldots \ldots \ldots \ldots \ldots$
Clinical Examples $\ldots \ldots \ldots \ldots \ldots \ldots \ldots \ldots \ldots$

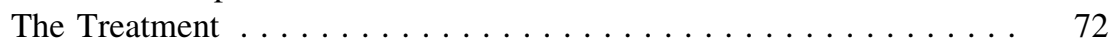

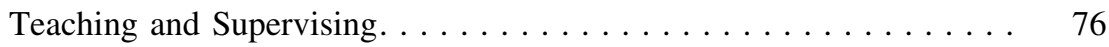

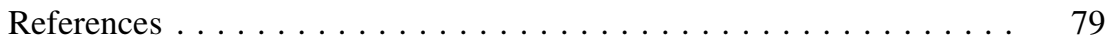




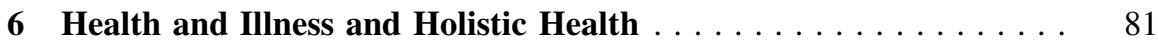

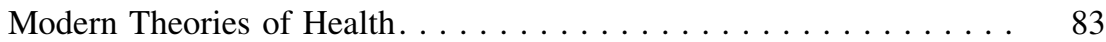

Holistic Health . . . . . . . . . . . . . . . . . . 85

Holistic Health in Terms of the Phenomenological

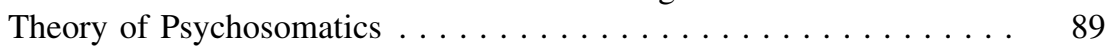

References ........................... 94

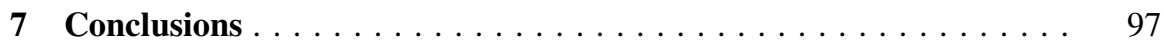

Reference.......................... 101

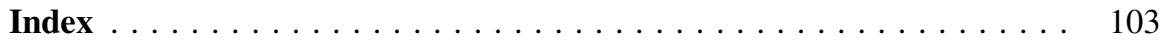




\section{Introduction}

The patient who presents somatic symptoms with no clearly discernible lesion or dysfunction presents a problem to the traditional health care system. These symptoms are medically unexplainable (so-called "MUS" = medically unexplained symptoms) and thus constitute an anomaly for the materialistic understanding of health problems that underlies the practice of modern medicine. The history of Western medicine is the story of how the body gradually revealed its internal mysteries, after human dissection was approved, (formally permitted in 1565 at London's Royal College of Physicians), resulting in the conceptualization of disease and ill health in terms of identifiable abnormalities in the body. The discovery of viruses and bacteria further solidified the explanatory power of material "stuff" in the body as pathogenic, while the coming of modern technologies allowed for an even further level of material discernment by augmenting the eye of the doctor through sophisticated machinery and laboratory tests. These advances have made possible the cure and prevention of many diseases and are very useful for those conditions that can be properly understood in material terms. However, this traditional biomedical model is not appropriate for understanding a number of health issues that we call "psychosomatic" and for this reason, biomedical theory and practice must be complemented in order to adequately understand and treat the psychosomatic anomaly. This book is an attempt to establish a complementary understanding of health and illness in terms of a non-reductionist model allowing for the psychosomatic expression of the lived body. The term "lived body" comes from the philosophy of Maurice MerleauPonty, and it is his work which will be the theoretical inspiration for the alternative understanding of psychosomatics worked out in these chapters. 